\title{
Application of Task-oriented Teaching Method in Teaching Reform of International Business Major
}

\author{
Shuhua Zi, Lei Tian \\ School of Business Administration, Qilu University of Technology, Ji'nan, 250353, China
}

Keywords: Task-oriented teaching method, International business, Teaching reform

\begin{abstract}
At present, China's international business teaching also has certain problems which generate adverse effects on cultivation of high-quality international business talents and go against further development of foreign trade in current society. This paper combines the significance of task-oriented teaching application in international business teaching, analyzes the causes for the problems existing in current international business teaching proposes corresponding reform measures in allusion to these causes and hopes to further improve teaching level of international business major through task-oriented teaching method and offer guarantee for high-quality international business talents.
\end{abstract}

\section{Introduction}

Under the social background of integration of world economy, China's reform and opening-up obtain deep development. As China officially joined WTO, the course of integration of domestic market and international market further speeds up, and international trading activities gradually present diversified and wide-field development trend. According to prediction of relevant departments, the demand of China's economic field for international business talents will certainly be on the rise within future 10 years. The demand quantity will even break through 2 million. But influenced by education quality of international business major in colleges, students' employment difficulty is still severe. Course setting rationality of international business major is low; teaching method is obsolete and rigid; students lack experience in post practice. These problems impose huge impacts on improvement of employment competitiveness. Thus, in current stage, China's relevant education departments should pay more attention to teaching reform of international business major, further improve teaching level through reform and create conditions for improvement of employment competitiveness.

\section{Significance of task-driven teaching mode application in teaching reform of international business major in colleges}

With deep development of integration of world economy, Chinese enterprises start to take active part in relevant international trading activities and foreign trade presents favorable development momentum. In 2014, China's gross value of import and export broke through RMB 26400 billion, up $2.3 \%$ year on year. Gross export value increased by $4.9 \%$, while predicted global trade value only increased by $2 \%$. This indicates growth rate of China's foreign trade has been obviously higher than global mean growth rate. Rapid development of foreign trade promotes the gap of national trading talents gradually increase. This offers an extensive market for employment of international business graduates. Employment problem of students majoring in international business should be relived and even solved ${ }^{[1]}$. But, relevant survey shows after the students majoring in international business graduate, generally they cannot land satisfying jobs in international business. Many students have employment difficulties. This is mainly because students' low professional quality and enterprises' demand for high-quality talents have certain conflicts. This generates adverse effects on students' employment. Thus, in current stage, college international business teaching should correctly cognize social demand for comprehensive quality of talents, reconstruct more scientific market-oriented and employment-oriented teaching mode, change the current situations of low course setting rationality, improper teaching mode and excessive attention to theoretical teaching, regard cultivation of 
students' adaptive capacity for international business employment posts as the objective, actively organize students' participation in social practice, further improve students' theoretical knowledge application ability and professional skills and furthest meet enterprises' actual demand for talents. International business teaching reform under the guidance of task-oriented teaching theory can effectively reform these problems, further enhance students' employment competitiveness and generate positive influence on students' further development.

\section{Problems in college international business teaching}

In recent years, China's relevant departments have surveyed employment status of international business graduates. Some enterprises are unwilling to employ international business graduates which just enter society. This is mainly because these students generally have lo operation quality, lack social experience and cannot be qualified for the post in a short time. In this aspect, Chinese colleges have defects compared with traditional talent training mode. These defects restrict promotion of students' social practice ability, vocational positioning capability, vocational development ability, post adaptation ability and innovation ability and go against students' further development. Firstly, some colleges set at least 15 courses for students major in international business, hope to promote students' all-round development and cultivate students to become high-quality talents. However, since these courses are basically based on theory teaching and break away from social reality, students' knowledge cannot be really applied in social practice. Thus, students' theoretical knowledge reserve and practical ability differ greatly, and they are hard to find a job ${ }^{[2]}$. Secondly, vague employment direction also generates bad effects on employment of students majoring international business. Many colleges in China fail to specify training direction of international business talents, do not carefully analyze the demand of society and market for talents' qualities and abilities and cut apart the connection between talent supply and requisitioning parties in talent training. Thus, social adaptation of college graduates is relatively poor. This problem even affects enterprises' talent recruitment direction. In talent recruitment process, foreign trade enterprises generally will not explicitly indicate to recruit "international business" talents, but conceal demand and recruitment of international business talents in market survey, planning, promotion and negotiation positions. Then, they will carry out pre-post training and cultivation so as to boost talents' comprehensive quality. This problem causes students cannot pinpoint their employment direction, which seriously affects students' confidence in development prospect of international business major. Thirdly, the lack of occupational planning education restricts students' employment. College teachers of international business major generally lack social practice ability and can only conduct social practice training for students through actual case analysis in classroom teaching. The teaching effect is not idea $^{[3]}$. Generally, students pay no attention to vocational guidance education. Students' knowledge structure cannot adapt social demand so that students are faced with the risk of secondary unemployment due to poor practice ability even if they smoothly enter international business industry after their graduation. This not merely influences development of international business students, but also restricts promotion of China's international trade level to some extent. Therefore, in current stage, educational reform of international business major has certain realistic significance under guidance of task-oriented teaching method.

\section{Application of task-driven teaching method in teaching reform of college international business major}

Focus on major foundation to set task course link

During selection of market-oriented professional technology system course, an important principle is to combine application of professional technology in practical work, and regard work task as the driving force to choose and set courses. Professional technology of international business has very strong applicability and involves extensive knowledge and skills of commodity import and export. Fundamental foreign trade document work is taken for example. The job range involves bank, inspection, storage, packaging, transportation and customs departments. The job contents also 
include checking letter of credit, managing and preparing bills within the scope of letter of credit ${ }^{[4]}$. If teachers just simply complete some rigid unit course tasks in classroom teaching, teaching effect will be inevitably affected. Seeing from current teaching practice of college international business major, in order to boost deep development of teaching reform, it is required to combine social talent demand to construct more scientific teaching system, focus on professional technology to set course teaching tasks, construct corresponding "task course link" in combination of actual teaching needs, set a series of learning tasks in practice and gradually boost students' employment ability in the process of guiding and urging students to complete tasks. In task course link, courses in each link are composed of a group of contents with strong relevance, and are rationally arranged according to the progressive principle so as to make sure students' ability is improved gradually. Generally, students can master relevant professional skills through completing professional skill teaching in a unit link ${ }^{[5]}$. Meanwhile, task chain setting should regard cultivation of professional technical capability as a professional work task or occupational comprehensive task. Teaching activities are conducted according to hierarchical tasks to make sure students can really participate in social practice, enhance students' practice ability and boost students' comprehensive quality.

\section{Set targeted tasks and carry out module teaching}

Overall course system of college international business major mainly includes teaching contents of two important modules, i.e. professional basic knowledge theory module and professional skill module. Regardless of either module, the teaching contents can play certain urging role for students, then promote improvement of their learning efficiency and effect and facilitate their all-round development as long as they can apply task-oriented teaching method to set specific learning tasks for students. For instance, in teaching basic knowledge theory module, students should be bale to master basic knowledge about international business, while most students consider theoretical property of basic knowledge is too strong, and learning it has certain difficulty in understanding. At this time, teachers can set more visual learning tasks according to teaching contents, motivate students' learning interest, make students consciously and actively learn basic theory under task driving and boost learning effect of basic theoretical knowledge. For professional skill module teaching, teachers may properly design typical work-based learning tasks, make students continuously participate in social practice under task driving, enhance post adaptation ability and lay a solid foundation for future development. It is positive for students; growth and even national integrated development to blend task-oriented teaching method in international business teaching, guide students' autonomous learning, and facilitate their integrated development ${ }^{[6]}$.

\section{Promote students' comprehensive ability with life-based learning tasks}

International business major originates from life and offers corresponding services for social life. It extracts and compacts life and is also higher than life. In teaching practice, teachers may combine teaching features of international business major to design and allocate some life-based learning tasks for students, organize students to actively explore life after finishing study of professional knowledge, deepen understanding of professional knowledge and improve students' comprehensive quality. For instance, while teaching foreign trade packaging to students, teachers may guide students to carefully observe and analyze some classical packaging in daily life after finishing basic teaching, study packaging features and the reasons for success, organize students actively share their views on this issue in classroom discussion and put forward suggestions on improving relevant packaging ${ }^{[7]}$. On this basis, teachers may assign deeper-level tasks for students, require students to pack some products according to valuable experience learned in the last task learning and in combination of their understanding. This has positive influence on cultivating students' independent thinking ability and creation ability and contributes to promoting students' professional quality.

\section{Combine colleges and enterprises to make up for shortcomings of classroom teaching through enterprise practice}

Except setting various kinds of simulation learning tasks, teachers also should pay more attention to college-enterprise joint teaching in teaching process, provide corresponding practice opportunity for students in enterprises and offer practice opportunity for students' future social work and life. Since simulation task teaching just stimulates some working processes in international business work and 
offer visional learning environment for students, this contributes to promoting students' comprehensive quality, but students impossibly really know and experience practical work of international business companies from this teaching mode. This to some extent restricts further development of students' social practice ability ${ }^{[8]}$. Thus, in order to improve students' comprehensive quality and cultivate talents meeting social demand, colleges should enhance college-enterprise cooperation, organize teachers to lead students to train in enterprises, invite enterprise employees with rich experience to carry out corresponding lectures and reports at colleges, and let students absorb lessons, enrich and improve themselves continuously.

\section{Conclusions}

In conclusion, in current stage, some problems still exist in college international business teaching. These problems impose adverse impacts on training students' comprehensive quality and improving social practice ability. Therefore, colleges should actively explore new teaching mode, change traditional teaching idea, attach importance to enhancing students' social practice ability, cultivate students to talents who can meet social demand and facilitate continuously development of China's international trade.

\section{References}

[1] Zhuo Zhenyun, Task-oriented teaching reform of international business major in higher vocational colleges. Jintian, 2012(12):162-163.

[2] Tang Rongquan, Application of “project introduction, task-driven”teaching mode in finance and economics teaching in higher vocational colleges. Jin Se Nian Hua (II), 2013(2):26-26.

[3] Yuan Jianchang, Xu Jianmin, Teaching reform of international business major oriented to working process in higher vocational colleges. Vocational \& Technical Education Forum, 2012(8):32-33.

[4] Chen Yingyu, Business interpretation course reform of international business major based on typical working task in higher vocational colleges. Journal of Jiangsu Vocational and Technical Institute, 2013(5):90-92.

[5] Yang Xiaoyong, Exploration of teaching mode of business English major based on typical working task in higher vocational colleges. China Education Innovation Herald, 2012(28):32-33.

[6] Shi Jingjing, Application of task-oriented teaching method in "Business English Translation and Interpretation" course in higher vocational colleges. Journal of Qiongzhou University, 2012,19(4):96-97.

[7] Liu Shi, Application of task-oriented teaching method in business English teaching. Journal of Liaoning Higher Vocational, 2013(6):30-32.

[8] Zheng Xiaoli, Application of task-oriented teaching method in marketing course in secondary vocational schools. Occupation, 2013(36):54. 